Pediat. Res. 1: 386-394 (1967)

Intestine metabolism

kidney hereditary disease

glucose $T m$ polyuria

\title{
Tm Glucose in a Case of Congenital Intestinal and Renal Malabsorption of Monosaccharides
}

\author{
H.-Y.Liu ${ }^{[58]}$, G.J.Anderson, M.U.Tsao, Barbara F. Moore and Zsuzsanna Giday \\ Department of Pediatrics and Communicable Diseases, University of Michigan Medical School, \\ Ann Arbor, Michigan, USA
}

Extract

Maximal rate of renal tubular reabsorption of glucose $\left(\mathrm{Tm}_{\mathrm{G}}\right)$ was determined in a 9-month-old girl with congenital intestinal malabsorption of glucose and galactose associated with constant glucosuria. At the time of the procedure, the patient had attained normal growth and development and was enjoying good health following a 5-month dietary regimen which excluded virtually all carbohydrates other than fructose. The standard glucose titration of renal tubules was carried out, using 4 arterial plasma glucose concentrations $\left(P_{G}\right)$, each maintained over 3 consecutive 20 -minute periods while the glomerular filtration rate was kept relatively constant. The following observations were made: 1. The rate of filtered glucose $\left(\mathrm{F}_{\mathrm{G}}\right)$ was found to exceed that of reabsorption $\left(\mathrm{T}_{\mathrm{G}}\right)$ at all $\mathrm{P}_{\mathrm{G}}$ levels ranging from 31 to $243 \mathrm{mg} \%$, revealing a very low renal plasma threshold. 2. A T $\mathrm{Tm}_{\mathrm{G}}$ of $76.7 \mathrm{mg} /$ $\min / 1.73 \mathrm{~m}^{2}$ was achieved at a $\mathrm{P}_{\mathrm{G}}$ level of $174 \mathrm{mg} \%$, when $\mathrm{F}_{\mathrm{G}} / \mathrm{T}_{\mathrm{G}}=1.35$. This amounts to $25 \%$ of the normal adult value, taken as $303 \mathrm{mg} / \mathrm{min} / 1.73 \mathrm{~m}^{2}$. Compared with data on premature and full-term newborns, it reflects a profound deficiency of tubular reabsorption of glucose in our patient. 3. A marked drop of $T_{G}$ was recorded during the final hour of titration with prolonged elevation of $F_{G}$; and the observation was felt to be valid. A search of the literature revealed that others have observed the same phenomenon in subjects with suboptimal tubular reabsorption of glucose relative to the filtered load.

\section{Speculation}

The finding of a low $\operatorname{Tm}_{G}$ in our patient with documented intestinal malabsorption of glucose and galactose strengthens Crane's original concept that a common mechanism mediates active transport of glucose at the intestinal and renal tubular epithelia. The marked drop of $T_{G}$ after prolonged elevation of $F_{G}$ in subjects with suboptimal tubular reabsorption of glucose seems to reflect a sudden 'fatigue' or inhibition of an already strained transport mechanism. It is postulated that this propensity for 'fatigue' or inhibition, by whatever processes, may be part of the profile of defective epithelial transport of glucose in these patients. 


\section{Introduction}

The active transport of glucose across mammalian small intestinal $[9,10,40,55]$ and renal tubular $[4,7$, $18,30,31,34,45,47,51,54]$ epithelia has long been a subject of intense interest. Certain parallelism between the structural $[6,39]$ and functional $[9,18,30]$ characteristics of the epithelial cells in these organs has made it attractive to postulate a common mechanism mediating glucose transport at both sites $[9,18,30]$. With the discovery, since 1962, of a group of patients suffering congenital intestinal as well as renal malabsorption of glucose and galactose [1, 20-28, 32, 42, 43], the concept of a common epithelial glucose transport mechanism in both organs has gained credence [11].

Although all reported patients with this congenital disorder have had documented mellituria, the urinary spill of reducing substances appears to occur at varying blood sugar levels in individual patients. Several authors have commented on the apparent lowering of renal threshold for glucose in these afflicted individuals $[1,28,32]$. But, to date, there has been no published data on the renal tubular transport maxima for glucose (Tm glucose) in any of the known cases.

The present report deals with the determination of Tm glucose in an infant with congenital intestinal and renal malabsorption of monosaccharides [27, 28], using the standard method of glucose titration of the renal tubules [47].

\section{Material and Methods}

Table I summarizes the pertinent clinical data on the patient L.W. at the time of the Tm glucose determination.

The rate of glucose reabsorption $\left(\mathrm{T}_{\mathrm{G}}\right)$ was calculated from the difference between filtered glucose $\left(\mathrm{F}_{\mathrm{G}}\right)$ and excreted glucose $\left(E_{G}\right)$, determined first at fasting arterial plasma glucose level; and again, when the latter was raised in successive stages up to 8-fold the fasting values, while the glomerular filtration rate (GFR) was kept relatively constant at each plasma glucose concentration. The highest $T_{G}$ achieved during the 4-hour titration was taken as the $\mathrm{Tm}_{\mathrm{G}}$. GFR was measured by means of inulin clearance $\left(\mathrm{C}_{\mathrm{in}}\right)$. Plasma glucose $\left(P_{G}\right)$ and inulin $\left(P_{\text {in }}\right)$ were determined on samples obtained through an indwelling femoral artery catheter; urinary glucose $\left(U_{G}\right)$, inulin $\left(U_{\text {in }}\right)$ and volume flow (V) were measured on samples collected via an indwelling catheter in the bladder.

A constant intravenous infusion, composed of $10 \%$ inulin (Warner-Chilcott, Morris Plains, New Jersey), $100 \mathrm{ml}, 0.9 \% \mathrm{NaCl}$ (USP), $200 \mathrm{ml}$ and $22.3 \% \mathrm{KCl}$ (USP), $8.6 \mathrm{ml}$, was administered to maintain an arterial plas- ma inulin concentration between 0.31 and $0.34 \mathrm{mg} / \mathrm{ml}$. Arterial glucose was maintained at the desired levels with $5 \%$ Dextrose (USP) intravenously after priming with $20 \%$ Dextrose (USP), using a constant infusion pump. Because of this baby's tendency toward massive glucosuria and osmotic diuresis when given glucose intravenously, a large volume of fluid was administered in order to balance the urine flow. Total parenteral fluid infusion rates for the 4 titration periods were 0.41 $\mathrm{ml} / \mathrm{min}, 2.32 \mathrm{ml} / \mathrm{min}, 4.23 \mathrm{ml} / \mathrm{min}$ and $4.23 \mathrm{ml} / \mathrm{min}$, respectively. In addition, water was given by gavage: $450 \mathrm{ml}$ ( $50 \mathrm{ml} / \mathrm{kg}$ body weight) two hours before the start of period I; and $225 \mathrm{ml}$ from midperiod IC through period II. The former established an adequate urine flow of $11 \mathrm{ml} / \mathrm{min} / 1.73 \mathrm{~m}^{2}$ at the outset of the titration, and the latter was found necessary for its maintenance in this patient (see Results).

Measurements of all necessary parameters were made over 3 consecutive 20-minute subperiods (A, B,

Table I. Clinical state of patient L.W. at the time of Tm glucose determination

\begin{tabular}{|c|c|}
\hline Age & 9 months \\
\hline Sex & female \\
\hline Height & $71.8 \mathrm{~cm}$ (75th percentile) \\
\hline Weight & $8.6 \mathrm{~kg}$ (50th percentile) \\
\hline Surface area & $0.44 \mathrm{~m}^{2}$ \\
\hline Glucosuria & constant \\
\hline $\begin{array}{l}\text { State of health and } \\
\text { hydration }\end{array}$ & $\begin{array}{l}\text { excellent. No hyperglycemia, } \\
\text { hypertention, infection, } \\
\text { clinically evident cardio- } \\
\text { vascular, endocrine or } \\
\text { glomerular disease. Polyuria } \\
\text { present. No medication given. }\end{array}$ \\
\hline $\begin{array}{l}\text { Interval since last } \\
\text { gastrointestinal } \\
\text { symptoms due to } \\
\text { dietary glucose or } \\
\text { galactose }\end{array}$ & 5 months \\
\hline
\end{tabular}

Diet

1. lamb-corn oil-fructose formula [28]:

a) $1200-1500 \mathrm{ml} / 24 \mathrm{~h}$

b) $800-1000 \mathrm{cal} / 24 \mathrm{~h}$, of which $41 \%$ was derived from fat; $38 \%$ from $\mathrm{CHO}$; and $20 \%$ from proteins

2. Di-calcium phosphate

$0.5 \mathrm{~g}$ twice a day

3. Zymadrops ${ }^{\circledR}-0.6 \mathrm{cc} /$ day 
C) at the low (I), and again, progressively higher plasma glucose levels (II, III, IV). Thirteen to $15 \mathrm{~min}$ utes were allowed for the equilibration of $\mathrm{P}_{\mathrm{G}}$ before beginning each of the periods II, III and IV. The final two minutes of each subperiod began with urine sampling via thorough emptying of the bladder by means of Crede, washing with $20 \mathrm{ml}$ of water, followed by $10 \mathrm{ml}$ of air and extrusion of the last bubble from the urinary catheter, the latter signaling the iniation of a new subperiod. Arterial samplings were made exactly 10 minutes following the beginning of $\mathrm{A}, \mathrm{B}$ and $\mathrm{C}$.

All collected samples of urine and blood were placed on ice immediately, centrifuged, deproteinated and analyzed for glucose and inulin, using the glucose oxidase (Glucostat) [17], and modified RoE [44] methods respectively.

The patient remained recumbent, unsedated, often asleep during the procedure, but would chatter, play with toys and keep one member of the team singing, rocking and supplying entertainment while she was awake.

Calculations: Values derived from each of the 20minute subperiods $(A, B, C)$ were averaged to yield the representative means for periods I, II, III and IV, technically unacceptable data not being included in the calculations.

$\mathrm{C}_{\mathrm{in}}=\frac{\mathrm{U}_{\mathrm{in}} \times \mathrm{V}}{\mathrm{P}_{\mathrm{in}}} ; \mathrm{F}_{\mathrm{G}}=\mathrm{P}_{\mathrm{G}} \times \mathrm{C}_{\mathrm{in}} ; \mathrm{E}_{\mathrm{G}}=\mathrm{U}_{\mathrm{G}} \times \mathrm{V}$

$\mathrm{C}_{\mathrm{G}}$ (glucose clearance) $=\frac{\mathrm{U}_{\mathrm{G}} \mathrm{V}}{\mathrm{P}_{\mathrm{G}}}$

$\mathrm{T}_{\mathrm{G}}=\mathrm{F}_{\mathrm{G}}-\mathrm{E}_{\mathrm{G}}=\mathrm{P}_{\mathrm{G}} \times \mathrm{C}_{\mathrm{in}}-\mathrm{U}_{\mathrm{G}} \times \mathrm{V}$
Results

\section{Data and Calculations (table II)}

Due to the patient's professed thirst, known tendency toward polyuria, yet small urine flow $(1.32$ to $1.97 \mathrm{ml}$ / $\left.\min / 1.73 \mathrm{~m}^{2}\right)$ in periods $\mathrm{I}_{\mathrm{B}}$ and $\mathrm{I}_{\mathrm{G}}$, to circumvent dehydration and ensure adequate urine flow, a total of $225 \mathrm{ml}$ of water was fed by gavage via an indwelling nasopharyngeal catheter, beginning at midperiod $\mathrm{I}_{\mathrm{C}}$ and extending throughout period II. Water diuresis ensued and persisted through periods II and III, during which urine specific gravity fell to 1.003-1.005; urine flow averaged $16.4 \mathrm{ml} / \mathrm{min} / 1.73 \mathrm{~m}^{2}$; and inulin $\mathrm{U} / \mathrm{P}$ ratio ranged from 2.7 to 4.7 . Osmotic diuresis probably began contributing to the enhanced urine flow during period III with significant rise of urine glucose; while the sustained diuresis ( $\mathrm{V}=7.9$ to 14.2 $\mathrm{ml} / \mathrm{min} / 1.73 \mathrm{~m}^{2}$ ) of period IV was perhaps largely secondary to the marked glucosuria at this time. During period $\mathrm{II}_{\mathrm{C}}$, in addition to a $60 \%$ increase in $\mathrm{V}$, there was a concomitant $30 \%$ drop of $\mathrm{P}_{\text {in }}$, both contributing to a corresponding increase of $\mathrm{C}_{\mathrm{in}}$ far above the mean value for period II. This $\mathrm{C}_{\mathrm{in}}$, derived from an unstable $P_{\text {in }}$, was felt to be spurious and excluded from calculations. Throughout the water diuresis of periods II and III, average $\mathrm{C}_{\text {in }}$ rose by $26.9 \%$ over the mean for the entire titration without significant variation from one subperiod to another.

$\mathrm{P}_{\mathrm{G}}$ samples from $\mathrm{III}_{\mathrm{B}}$ and $\mathrm{III}_{\mathrm{C}}$ were lost, but there was no reason to expect significant deviation of these values from that of $\mathrm{III}_{\mathrm{A}}$, since $\mathrm{P}_{\mathrm{G}}$ for each subperiod tended to remain quite stable in this titration, and since other parameters had varied little throughout the

Table II. Measured and calculated data during glucose titration in patient L.W. ${ }^{1}$

\begin{tabular}{|c|c|c|c|c|c|c|c|}
\hline Period & $\begin{array}{l}\mathrm{P}_{\mathrm{G}} \\
(\mathrm{m} \mathrm{m} / \mathrm{ml})\end{array}$ & $\begin{array}{l}\mathrm{C}_{\mathrm{in}} \\
(\mathrm{ml} / \mathrm{min})\end{array}$ & $\begin{array}{l}\mathrm{U}_{\mathrm{G}} \\
(\mathrm{mg} / \mathrm{ml})\end{array}$ & $\begin{array}{l}\mathrm{V} \\
(\mathrm{ml} / \mathrm{min})\end{array}$ & $\begin{array}{l}\mathrm{F}_{\mathrm{G}} \\
(\mathrm{mg} / \mathrm{min})\end{array}$ & $\begin{array}{l}\mathrm{T}_{\mathrm{G}} \\
(\mathrm{mg} / \mathrm{min})\end{array}$ & $\begin{array}{l}\text { Average } T_{G} \\
(\mathrm{mg} / \mathrm{min})\end{array}$ \\
\hline $\mathrm{I}_{\mathrm{A}}$ & 0.31 & 8.47 & 0.035 & 4.6 & 2.63 & 2.47 & \multirow{3}{*}{2.50} \\
\hline $\mathrm{I}_{\mathrm{B}}$ & 0.30 & 9.51 & 0.073 & 0.5 & 2.85 & 2.82 & \\
\hline $\mathrm{I}_{\mathrm{G}}$ & 0.33 & 6.84 & 0.116 & 0.35 & 2.26 & 2.22 & \\
\hline $\mathrm{II}_{\mathrm{A}}$ & 0.65 & 13.1 & 0.125 & 0.75 & 8.52 & 8.42 & \multirow{2}{*}{9.91} \\
\hline $\mathrm{II}_{\mathrm{B}}$ & 0.70 & 16.9 & 0.094 & 4.13 & 11.8 & 11.4 & \\
\hline $\mathrm{II}_{\mathrm{C}}$ & 0.71 & -2 & 0.074 & 5.45 & & & \multirow{4}{*}{19.5} \\
\hline $\mathrm{III}_{\mathrm{A}}$ & 1.74 & 15.2 & 1.22 & 5.7 & 26.5 & 19.5 & \\
\hline $\operatorname{III}_{\mathrm{B}}$ & $-{ }^{2}$ & 17.7 & 2.10 & 5.4 & & & \\
\hline $\mathrm{III}_{\mathrm{C}}$ & $-{ }^{2}$ & 16.3 & 1.40 & 4.75 & & & \\
\hline$I V_{\mathrm{A}}$ & 2.56 & 8.82 & 6.0 & 3.25 & 22.6 & 3.08 & \multirow{3}{*}{2.60} \\
\hline $\mathrm{IV}_{\mathrm{B}}$ & 2.36 & 9.10 & 9.83 & 2 & 21.5 & 1.82 & \\
\hline$I V_{\mathrm{C}}$ & 2.36 & 11.5 & 6.73 & 3.6 & 27.1 & 2.91 & \\
\hline
\end{tabular}

${ }^{1}$ Abbreviations used: $\mathrm{P}_{\mathrm{G}}$, arterial plasma glucose; $\mathrm{C}_{\mathrm{in}}$, inulin clearance; $\mathrm{U}_{\mathrm{G}}$, urine glucose; $\mathrm{V}$, urine flow; $\mathrm{F}_{\mathrm{G}}$, filtered glucose; $\mathrm{T}_{\mathrm{G}}$, reabsorbed glucose.

2 Data discarded because of technical error. 
Tm glucose in a case of congenital intestinal and renal malabsorption of monosaccharides 389

Table III. Tubular reabsorption of glucose by patient L.W. relative to arterial plasma and filtered glucose

\begin{tabular}{lllll}
\hline Periods & $\begin{array}{l}\text { Arterial plasma glucose } \\
\left(\mathrm{P}_{\mathrm{G}}\right)(\mathrm{mg} / \mathrm{ml})\end{array}$ & $\begin{array}{l}\text { Filtered glucose }\left(\mathrm{F}_{\mathrm{G}}\right) \\
(\mathrm{mg} / \mathrm{min})\end{array}$ & $\begin{array}{l}\text { Reabsorbed glucose }\left(\mathrm{T}_{\mathrm{G}}\right) \\
(\mathrm{mg} / \mathrm{min})\end{array}$ & $\mathrm{F}_{\mathrm{G}} / \mathrm{T}_{\mathrm{G}}$ \\
\hline I & 0.31 & 2.58 & 2.50 & 1.03 \\
II & 0.67 & 10.16 & 9.91 & 1.03 \\
III & 1.74 & 26.40 & $19.50\left(\mathrm{Tm}_{\mathrm{G}}\right)$ & 1.35 \\
IV & 2.43 & 23.70 & 2.60 & 9.12 \\
\hline
\end{tabular}

Table IV. Comparison of all measured and calculated data obtained during periods I and IV of glucose titration in patient L.W. ${ }^{1}$

\begin{tabular}{|c|c|c|c|c|c|c|c|}
\hline Periods & $\begin{array}{l}\mathrm{P}_{\mathrm{G}} \\
(\mathrm{mg} / \mathrm{ml})\end{array}$ & $\begin{array}{l}\mathrm{C}_{\text {in }} \\
(\mathrm{ml} / \mathrm{min})\end{array}$ & $\begin{array}{l}U_{G} \\
(\mathrm{mg} / \mathrm{ml})\end{array}$ & $\begin{array}{l}\mathrm{V} \\
(\mathrm{ml} / \mathrm{min})\end{array}$ & $\begin{array}{l}\mathrm{F}_{\mathrm{G}}= \\
\mathrm{P}_{\mathrm{G}} \times \mathrm{C}_{\mathrm{in}} \\
(\mathrm{mg} / \mathrm{min})\end{array}$ & $\begin{array}{l}\mathrm{T}_{\mathrm{G}}=\mathrm{P}_{\mathrm{G}} \times \mathrm{C}_{\mathrm{in}} \\
-\mathrm{U}_{\mathrm{G}} \times \mathrm{V} \\
(\mathrm{mg} / \mathrm{min})\end{array}$ & $\begin{array}{l}\text { Average } T_{G} \\
(\mathrm{mg} / \mathrm{min})\end{array}$ \\
\hline $\mathrm{I}_{\mathrm{A}}$ & 0.31 & 8.47 & 0.035 & 4.6 & 2.63 & 2.47 & \multirow{3}{*}{2.50} \\
\hline $\mathrm{I}_{\mathrm{B}}$ & 0.30 & 9.51 & 0.073 & 0.5 & 2.85 & 2.82 & \\
\hline $\mathrm{I}_{\mathrm{C}}$ & 0.33 & 6.84 & 0.116 & 0.35 & 2.26 & 2.22 & \\
\hline $\mathrm{IV}_{\mathrm{A}}$ & 2.56 & 8.82 & 6.0 & 3.25 & 22.6 & 3.08 & \multirow{3}{*}{2.60} \\
\hline$I V_{B}$ & 2.36 & 9.10 & 9.83 & 2.0 & 21.5 & 1.82 & \\
\hline $\mathrm{IV}_{\mathrm{C}}$ & 2.36 & 11.5 & 6.73 & 3.6 & 27.1 & 2.91 & \\
\hline
\end{tabular}

${ }^{1}$ For abbreviations, see table II.

subperiods of III. Nevertheless, data from $\mathrm{III}_{B}$ and III $_{\mathrm{C}}$ were excluded from calculations.

Validity of $\mathrm{T}_{\mathrm{G}}$ calculated from the mean of $\mathrm{II}_{\mathrm{A}}$ and $\mathrm{II}_{\mathrm{B}}$ and, again, from the single period of $\mathrm{III}_{\mathrm{A}}$ may be verified as follows: 1 . Substituting the mean $\mathrm{C}_{\text {in }}$ of $\mathrm{II}_{\mathrm{A}}$ and $\mathrm{II}_{\mathrm{B}}$ for that of $\mathrm{II}_{\mathrm{C}}$, the calculated mean $\mathrm{T}_{\mathrm{G}}$ for period II would be $9.69 \mathrm{mg} / \mathrm{min}$, compared to 9.91 $\mathrm{mg} / \mathrm{min}$ derived from averaging data of $\mathrm{II}_{\mathrm{A}}$ and $\mathrm{II}_{B}$; 2. assuming $\mathrm{P}_{\mathrm{G}}$ for $\mathrm{III}_{\mathrm{B}}$ and $\mathrm{III}_{\mathrm{C}}$ to be constant and equal to that of $\mathrm{III}_{A}$, and using the average $\mathrm{C}_{\mathrm{in}}$ of III $_{A}, B, C$, the calculated mean $T_{G}$ of period III would be $19.53 \mathrm{mg} / \mathrm{min}$, compared to $19.5 \mathrm{mg} / \mathrm{min}$ derived from the titration data of $\operatorname{III}_{\mathrm{A}}$ alone. Thus, the mean values of $T_{G}$ obtained for the 4 titration periods (tables II and III) may be considered valid even though data from periods $\mathrm{II}_{\mathrm{C}}, \mathrm{III}_{\mathrm{B}}$ and $\mathrm{III}_{\mathrm{C}}$ were excluded from the final analysis.

\section{Tubular Reabsorption of Glucose Relative to the Filtered Load}

Table III lists the mean values of the parameters essential for the characterization of tubular glucose reabsorption during the 4 test periods. It is noteworthy that 1. at all arterial plasma glucose levels $\left(P_{G}\right)$, the rate of filtered glucose $\left(\mathrm{F}_{\mathrm{G}}\right)$ always exceeded that of reabsorption $\left(\mathrm{T}_{\mathrm{G}}\right) ; 2$. in period III, when the rate of reabsorption had reached maximal efficiency $\left(\mathrm{Tm}_{\mathrm{G}}\right)$, the gap between $\mathrm{F}_{\mathrm{G}}$ and $\mathrm{T}_{\mathrm{G}}$ had significantly widened in comparison with those found in the two previous periods, $\mathrm{T}_{\mathrm{G}}$ now being less than $80 \%$ of $\mathrm{F}_{\mathrm{G}}$, or, $\mathrm{F}_{\mathrm{G}} / \mathrm{T}_{\mathrm{G}}$ $=1.35$; and 3 . when $P_{G}$ and $F_{G}$ had been raised to 8- and 9-folds of the initial levels respectively, $\mathrm{T}_{\mathrm{G}}$ exhibited a marked fall to a rate found at the beginning of the procedure.

To exclude errors of observation and calculation as possible causes of such dramatic failure of $T_{G}$ during period IV, the measured and calculated parameters obtained during each of the 20-minute subperiods $(\mathrm{A}, \mathrm{B}, \mathrm{C})$ in I and IV were compared, as presented in table IV. From these data, it is clear that: 1. since the measured $\mathrm{P}_{\mathrm{G}}$ and $\mathrm{C}_{\mathrm{in}}$ and the calculated $\mathrm{F}_{\mathrm{G}}$ and $\mathrm{T}_{\mathrm{G}}$ remained fairly constant throughout the subperiods of I, and again, of IV, these values are valid [46, 47]; and 2. in this patient, a 9-fold rise of $\mathrm{F}_{\mathrm{G}}$ was accompanied by essentially the same $T_{G}$ during the initial and the final phases of the 4-hour-titration procedure.

A $\operatorname{Tm}_{G}$ of $19.5 \mathrm{mg} / \mathrm{min}$ - as achieved during period III (table III). Corrected for surface area, $\mathrm{Tm}_{\mathrm{G}}=$ $76.7 \mathrm{mg} / \mathrm{min} / 1.73 \mathrm{~m}^{2}$.

Following the procedure, this baby showed no changes in body weight, fever, dehydration or anemia. The electrolyte levels in serum were normal. Less than 4,000 colonies of $\mathrm{E}$. coli per $\mathrm{ml}$ were cultured from a 'clean-catch' urine. 
Table V. Fall in $\mathrm{T}_{\mathrm{G}}$ or $\frac{\mathrm{T}_{\mathrm{G}}}{\mathrm{Tm}_{\mathrm{G}}}$ greater than $10 \%$ concomitant with rise in $\mathrm{F}_{\mathrm{G}}$ during $\mathrm{Tm}_{\mathrm{G}}$ determinations

\begin{tabular}{|c|c|c|c|c|c|c|c|c|}
\hline \multirow[t]{2}{*}{ Reference } & \multirow[t]{2}{*}{ Diagnosis } & \multirow[t]{2}{*}{ Subject } & \multirow[t]{2}{*}{$\Delta \mathrm{P}_{\mathrm{G}}$} & \multirow[t]{2}{*}{$\triangle \mathrm{GFR}$} & \multirow{2}{*}{$\begin{array}{l}\text { Fall of } T_{G} \\
(\mathrm{mg} / \mathrm{min})\end{array}$} & \multirow{2}{*}{$\begin{array}{l}\text { Fall of } \\
\mathrm{T}_{\mathrm{G}} / \mathrm{Tm}_{\mathrm{G}}{ }^{2}\end{array}$} & \multicolumn{2}{|c|}{ Fall of } \\
\hline & & & & & & & $\begin{array}{l}\mathrm{T}_{\mathrm{G}} \\
(\%)\end{array}$ & $\begin{array}{l}\mathrm{T}_{\mathrm{G}} / \mathrm{Tm}_{\mathrm{G}} \\
(\%)\end{array}$ \\
\hline $\begin{array}{l}\text { GovaERTS and } \\
\text { MULLER } 1939 \\
{[15]}\end{array}$ & $\begin{array}{l}\text { diabetes mellitus } \\
\text { (Pancreatectom- } \\
\text { ized) }\end{array}$ & $\operatorname{dog}$ III & + & - & 394 to 308 & & 21.8 & \\
\hline $\begin{array}{l}\text { Smith et al. } \\
1943 \text { [47] }\end{array}$ & $\begin{array}{l}\text { essential hyper- } \\
\text { tention with } \\
\text { large 'splay' in } \\
\text { titration curve }\end{array}$ & $\begin{array}{l}\text { B.S. } \% \text {, } \\
44 \text { years } \\
\text { A.M. + } \\
50 \text { years }\end{array}$ & & $\begin{array}{l}+ \\
+\end{array}$ & & $\begin{array}{l}0.96 \text { to } 0.81 \\
1.1 \text { to } 0.69 \\
0.98 \text { to } 0.81\end{array}$ & & $\begin{array}{l}15.6 \\
37 \\
17.3\end{array}$ \\
\hline $\begin{array}{l}\text { NIELSEN } 1948 \\
\text { [35] }\end{array}$ & "normal' man & $\begin{array}{l}0 \\
23 \text { years }\end{array}$ & + & + & 334 to 281 & & 15.9 & \\
\hline & $\begin{array}{l}\text { diabetes mellitus } \\
\text { with low } \operatorname{Tm}_{\mathrm{G}}\end{array}$ & $\begin{array}{l}\text { o, } \\
55 \text { years }\end{array}$ & + & - & 262 to 208 & & 20.6 & \\
\hline $\begin{array}{l}\text { BRADLEY et al. } \\
1950 \text { [2] }\end{array}$ & $\begin{array}{l}\text { renal } \\
\text { glycosuria }\end{array}$ & D.A. & & & & 1.04 to 0.92 & & 11.1 \\
\hline ReubI 1951 [37] & $\begin{array}{l}\text { renal glycosuria } \\
\text { with large } \\
\text { 'splay'3 }\end{array}$ & $\begin{array}{l}\text { K.B. } \\
\text { F.L. }\end{array}$ & $\begin{array}{l}+ \\
+\end{array}$ & + & $\begin{array}{l}304 \text { to } 268 \\
144 \text { to } 103\end{array}$ & & $\begin{array}{l}11.8 \\
28.5\end{array}$ & \\
\hline $\begin{array}{l}\text { ROBERTSON and } \\
\text { Gray } 1953 \text { [41] }\end{array}$ & diabetes mellitus & $\begin{array}{l}\text { case } 13 \\
\text { q }\end{array}$ & + & & 346 to 310 & & 10.4 & \\
\hline REUBI 1954 [38] & $\begin{array}{l}\text { renal } \\
\text { glycosuria }\end{array}$ & $\begin{array}{l}\text { H.E. } \\
\text { P.K. }\end{array}$ & & $\begin{array}{l}0 \\
0\end{array}$ & & $\begin{array}{l}1.31 \text { to } 1.00 \\
1.55 \text { to } 0.45\end{array}$ & & $\begin{array}{l}23.7 \\
71\end{array}$ \\
\hline $\begin{array}{l}\text { LAMBERT } 1954 \\
{[19]}\end{array}$ & $\begin{array}{l}\text { renal } \\
\text { glycosuria } \\
\text { mercury } \\
\text { poisoning }\end{array}$ & $\begin{array}{l}\text { Tim-ỡ } \\
20 \text { years }\end{array}$ & $\begin{array}{l}+ \\
+\end{array}$ & - & $\begin{array}{l}136.2 \text { to } 111.5 \\
9.75 \text { to } 4.63\end{array}$ & & $\begin{array}{l}18.1^{1} \\
52.5\end{array}$ & \\
\hline $\begin{array}{l}\text { FROESCI et al. } \\
1957 \text { [13] }\end{array}$ & $\begin{array}{l}\text { renal } \\
\text { glycosuria }\end{array}$ & E.T. & & & 46 to $34^{2}$ & & 26.1 & \\
\hline $\begin{array}{l}\text { STEIGERWALD } \\
1957[50]\end{array}$ & $\begin{array}{l}\text { renal } \\
\text { glycosuria }\end{array}$ & Fl. & & & & 1.0 to 0.75 & & 25 \\
\hline
\end{tabular}

1 Titration done with descending $\mathrm{P}_{\mathrm{G}}$

2 Values derived by means of visual approximation from authors' graphs

3 'Splay'-see [46]

\section{Comments}

During water diuresis of periods II and III, GFR exhibited a prompt and fairly stable $27 \%$ elevation over the mean value of the entire titration period. Although $\mathrm{C}_{\text {in }}$ did decrease subsequently in period IV, it is important to note that this decrease was accompanied by elevated urine flow, urine glucose concentration and glucose-inulin clearance ratio, their respective values being 7.9 to $14.2 \mathrm{ml} / \mathrm{min} / 1.73 \mathrm{~m}^{2} ; 6.0$ to $9.83 \mathrm{mg} / \mathrm{ml}$; and 0.9 . As long as GFR remained sufficiently high to ensure adequate urine flow and $F_{G} / T_{G}$ ratio, $T m_{G}$ has been found to be independent of changes in filtration rate in normal dogs $[45,46]$, healthy female human adults [47], and men and women under the influence of adrenalin, caffeine and hyperemia [47].

That $U_{G}$ has a finite value, even at the low $P_{G}$ of $0.31 \mathrm{mg} / \mathrm{ml}$, demonstrates a decidedly low renal plasma threshold for glucose in this patient [33]. This corroborates the earlier documentation of marked glucosuria (28.7 to $36.0 \mathrm{mg}$ glucose $/ 100 \mathrm{ml}$ urine) in this patient during an asymptomatic hypoglycemic period with 
Tm glucose in a case of congenital intestinal and renal malabsorption of monosaccharides 391 Table VI. Fall in $\mathrm{T}_{\mathrm{G}}, \frac{\mathrm{T}_{\mathrm{G}}}{\mathrm{T}_{\mathrm{G}}}$, or $\frac{\mathrm{T}_{\mathrm{G}}}{\mathrm{GFR}}$ less than $10 \%$ concomitant with rise in $\mathrm{F}_{\mathrm{G}}$ during $\mathrm{Tm}_{\mathrm{G}}$ determinations

\begin{tabular}{|c|c|c|c|c|c|c|c|c|}
\hline \multirow[t]{2}{*}{ Reference } & \multirow[t]{2}{*}{ Diagnosis } & \multirow[t]{2}{*}{ Subject } & \multirow[t]{2}{*}{$\Delta \mathrm{P}_{\mathrm{G}}$} & \multirow[t]{2}{*}{$\triangle \mathrm{GFR}$} & \multirow{2}{*}{$\begin{array}{c}\text { Fall of } \mathrm{T}_{\mathrm{G}} \\
(\mathrm{mg} / \mathrm{min})\end{array}$} & \multirow{2}{*}{$\begin{array}{l}\text { Fall of } \\
\mathrm{T}_{\mathrm{G}} / \mathrm{Tm}_{\mathrm{G}}{ }^{2} \\
\text { or } \\
\mathrm{T}_{\mathrm{G}} / \mathrm{GFR}^{2}\end{array}$} & \multicolumn{2}{|c|}{$\%$ Fall of } \\
\hline & & & & & & & $\mathrm{T}_{\mathrm{G}}$ & $\begin{array}{l}\mathrm{T}_{\mathrm{G}} / \mathrm{Tm}_{\mathrm{G}} \\
\text { or } \\
\mathrm{T}_{\mathrm{G}} / \mathrm{GFR}\end{array}$ \\
\hline $\begin{array}{l}\text { Sмith et al. } \\
1943 \text { [47] }\end{array}$ & $\begin{array}{l}\text { essential } \\
\text { hypertention; } \\
\text { arteriosclerosis }\end{array}$ & $\begin{array}{l}\text { S.D. } \stackrel{\text {, }}{ } \\
60 \text { years }\end{array}$ & & & & $\begin{array}{l}\mathrm{T}_{\mathrm{G}} / \mathrm{Tm}_{\mathrm{G}} \\
0.98 \text { to } 0.95\end{array}$ & & $\begin{array}{l}\mathrm{T}_{\mathrm{G}} / \mathrm{Tm}_{\mathrm{G}} \\
3\end{array}$ \\
\hline $\begin{array}{l}\text { MrRsky and } \\
\text { NeLSON } 1943 \\
{[33]}\end{array}$ & $\begin{array}{l}\text { renal } \\
\text { glycosuria } \\
\text { Bright's disease }\end{array}$ & $\begin{array}{l}\text { R.T. } \\
\text { L.T. }\end{array}$ & $\begin{array}{l}+ \\
+\end{array}$ & $\begin{array}{l}+ \\
-\end{array}$ & $\begin{array}{l}76 \text { to } 75 \\
106 \text { to } 103\end{array}$ & & $\begin{array}{l}1.32^{1} \\
4.6^{1}\end{array}$ & \\
\hline $\begin{array}{l}\text { CoRCORAN } 1948 \\
{[8]}\end{array}$ & $\begin{array}{l}\text { renal } \\
\text { glycosuria } \\
\text { glomerulon- } \\
\text { ephritis }\end{array}$ & case 1 & + & - & 240 to 236 & & 1.67 & \\
\hline $\begin{array}{l}\text { NIELSEN } 1948 \\
{[35]}\end{array}$ & $\begin{array}{l}\text { diabetes mellitus } \\
\text { with low } \operatorname{Tm}_{\mathrm{G}}\end{array}$ & $\begin{array}{l}\text { क, } \\
54 \text { years }\end{array}$ & + & + & 175.3 to 170.7 & & 2.6 & \\
\hline $\begin{array}{l}\text { GovaERTS and } \\
\text { LAMBERT } 1949 \\
{[16]}\end{array}$ & $\begin{array}{l}\text { renal } \\
\text { glycosuria }\end{array}$ & Roul-ô & + & - & 111 to 104 & & $6.3^{1}$ & \\
\hline REUBI 1951 [37] & $\begin{array}{l}\text { renal glycosuria } \\
\text { essential hyper- } \\
\text { tention with } \\
\text { large 'splay' } 3\end{array}$ & $\begin{array}{l}\text { P.S. } \\
\text { R.S. } \\
\text { E.Z. }\end{array}$ & $\begin{array}{l}+ \\
+ \\
+\end{array}$ & $\begin{array}{l}- \\
+\end{array}$ & $\begin{array}{l}219 \text { to } 202 \\
153 \text { to } 147 \\
301 \text { to } 297\end{array}$ & & $\begin{array}{l}7.76 \\
3.9 \\
1.33\end{array}$ & \\
\hline REUBI 1954 [38] & $\begin{array}{l}\text { renal glycosuria } \\
\text { with large 'splay' }\end{array}$ & H.M. & & 0 & & $\begin{array}{l}\mathrm{T}_{\mathrm{G}} / \mathrm{GFR} \\
2.55 \text { to } 2.32\end{array}$ & & $\begin{array}{l}\mathrm{T}_{\mathrm{G}} / \mathrm{GFR} \\
9.4\end{array}$ \\
\hline $\begin{array}{l}\text { LAMBERT } 1954 \\
{[19]}\end{array}$ & renal glycosuria & Sei- + & & & 108.5 to 105.7 & & $2.58^{1}$ & \\
\hline $\begin{array}{l}\text { FROESCH et al. } \\
1957 \text { [13] }\end{array}$ & renal glycosuria & F.N. & & & 142 to $132^{2}$ & & 7.04 & \\
\hline $\begin{array}{l}\text { LOTSPEKCH and } \\
\text { WorONKOW } \\
1958[29]\end{array}$ & phlorizinized dog & & - & + & 102 to 94 & & 7.84 & \\
\hline $\begin{array}{l}\text { BRADLEY et al. } \\
1961 \text { [3] }\end{array}$ & 'normal' dog & Cora & + & + & 229 to 209 & & 8.73 & \\
\hline
\end{tabular}

1 Titration done with descending $P_{G}$

${ }^{2}$ Values derived by means of visual approximation from authors' graphs

3 'Splay'-see [46] 
arterial concentration of total reducing substance amounting to $29 \mathrm{mg} \%$ [28].

$\mathrm{T}_{\mathrm{G}}$ in period III was the highest reabsorption rate attained during the titration, and it had a value less than $80 \%$ of $\mathrm{F}_{\mathrm{G}}$, or $\mathrm{F}_{\mathrm{G}} / \mathrm{T}_{\mathrm{G}}>1.25$. This $\mathrm{T}_{\mathrm{G}}$, then, by definition $[14,47]$, represents $\mathrm{Tm}_{\mathrm{G}}$. Thus, in our patient, $\mathrm{Tm}_{\mathrm{G}}=76.7 \mathrm{mg} / \mathrm{min} / 1.73 \mathrm{~m}^{2}$, which corresponds to $25 \%$ of the normal value in adults, taken as 303 $\mathrm{mg} / \mathrm{min} / 1.73 \mathrm{~m}^{2}$ [49]. By available standards even for premature [5, 52, 53] and full-term [52] newborns, some of whom were shown to be capable of achieving $58 \%$ [5] to $73 \%$ [52] of adult normal $\mathrm{Tm}_{\mathrm{G}}$ before 50 days of age, our 9-month-old patient exhibited a profound deficiency in renal tubular reabsorption of glucose. This resembles the state of her intestinal malabsorption of glucose and galactose [28], which, incidentally, exists independently of the influence of variable loading, thus representing a severe congenital membrane transport defect at both epithelial sites $[1,11,24$, $28,32,43]$.

The marked fall of $\mathrm{T}_{\mathrm{G}}$ to approximately $3.4 \%$ of adult normal $\mathrm{Tm}_{\mathrm{G}}$ in the face of continuously elevated $\mathrm{F}_{\mathrm{G}}$ in our observation was of particular interest. Even if the observed $40 \%$ decrease in GFR could be postulated to have deprived a portion of tubules from glucose loading in period IV, such a hypothetical mechanism would fall far short of a quantitative explanation for the measured $87 \%$ depression of $\mathrm{T}_{\mathrm{G}}$. Although $\mathrm{Tm}_{\mathrm{G}}$ has been said to remain relatively constant in any one normal individual, both human [49] and canine [45, 46], documentation exists for a fall of $T_{G}$ from $\operatorname{Tm}_{G}$ by as much as $1.3 \%$ to $71 \%$ with attainment of high $\mathrm{F}_{\mathrm{G}}$ rise (tables $\mathrm{V}$ and $\mathrm{VI}$ ). Such changes have been observed in patients with Bright's disease $[8,33]$, essential hypertension $[37,47]$, renal glycosuria $[2,8,13$, $16,19,33,37,38,50]$, diabetes mellitus $[35,41]$, mercury poisoning [19]; in pancreatectomized [15] or phlorizinized [29] dogs; and, occasionally, in the 'normal' man [35], dog [3] and cat [12], although in the latter, there is no statistical datum. Most authors have ignored this phenomenon, usually assuming this to be an artifact of technique and calculation. Indeed, SHANNON $[45,46]$ had warned against insufficient hydration, inadequate elevation or rapid fluctuations of $\mathbf{P}_{\mathrm{G}}$ during the procedure; and SMrTH [48] as well as NiELSEn [36] had cautioned about titrations carried out with low urine flow. On the other hand, when properly performed, this method contains an inherent error of only $\pm 5 \%[46,47]$. Thus, only some of the data in the literature revealing $\mathrm{T}_{\mathrm{G}}$ drop which exceeded $10 \%$ of $\mathrm{Tm}_{\mathrm{G}}$, concurrent with $\mathrm{F}_{\mathrm{G}}$ rise, are considered significant and listed in table $\mathrm{V}$. Those in table VI are included to lend qualitative support to the observations. It can be seen that: 1 . Eleven of the 16 separate glucose titrations listed in table $V$ recorded GFR changes. Of these, 4 showed rising, 3 showed unchanged and 4 showed dropping GFR accompanying the significant $\mathrm{T}_{\mathrm{G}}$ depression; 2. in all of the 30 titrations (tables $\mathrm{V}$ and VI), $T_{G}$ dropped as $F_{G}$ rose; and 3. with the exception of the one 'normal' man and the single 'normal' $\mathrm{dog}$, the lists were composed of 27 subjects with distinctly low $\operatorname{Tm}_{\mathrm{G}}$, large 'splay' in the titration curve or chronically elevated $F_{G}, 16$ of whom exhibited renal glycosuria, and 4, diabetes mellitus. It is pertinent that the 'normal' man in table $\mathrm{V}$ had an average $\mathrm{Tm}_{\mathrm{G}}$ of 302 $\mathrm{mg} / \mathrm{min}$ and $\mathrm{a} \mathrm{C}_{\mathrm{in}} / \mathrm{Tm}_{\mathrm{G}}$ of 0.458 , both of which reflect an average population of nephrons which would saturate and spill glucose at lower $\mathrm{P}_{\mathrm{G}}$ levels than the normal [47]. Similarly, the 'normal' dog cited here had achieved a $T m_{G}$ of $12 \mathrm{mg} / \mathrm{min} / \mathrm{kg}$ of body weight, which is in the lower range of normal values found by SHANNON [46]. Thus, it may be surmised that in certain types of kidneys, the maximal rate of tubular reabsorption of glucose may not be sustained after prolonged loading with high concentrations of filtered glucose; this need not require a drop in filtration rate, nor is it necessarily a technical artifact, in view of the number, diversity and competence of the observers enumerated. Rather, the common denominator in this phenomenon seems to be the type of subjects in whom it is most of ten observed, i.e., those with suboptimal renal tubular absorption of glucose relative to the filtered load, as if reflecting a sudden 'fatigue' or inhibition of an already strained transport mechanism. By whatever means, this propensity for 'fatigue' or inhibition may be part of the profile of defective epithelial transport of glucose in these patients.

\section{Summary}

Renal tubular transport maxima for glucose $\left(\mathrm{Tm}_{\mathrm{G}}\right)$ was determined, using the standard method of glucose titration of the renal tubules, in an infant girl with congenital intestinal and renal malabsorption of monosaccharides. Her $\mathrm{Tm}_{\mathrm{G}} / 1.73 \mathrm{~m}^{2}$ was found to be no more than $25 \%$ of adult normal values, with an apparent inability to maintain even this low level of function with prolonged elevation of the filtered load. It was postulated that such propensity for 'fatigue' or inhibition of the transport mechanism may be part of the underlying functional defect in these patients.

\section{References and Notes}

1. Anderson, C.M.; Kerry, K.R. and Townley, R.R.W.: An inborn defect of intestinal absorption of certain monosaccharides. Arch. Dis. Childh. 40: 1 (1965). 
Tm glucose in a case of congenital intestinal and renal malabsorption of monosaccharides 393

2. Bradley, S.E.; Bradley, G.P.; Tyson, C.J.; Gurry, J.J. and Blake, W.D.: Renal function in renal diseases. Amer.J.Med. 9: 766 (1950).

3. Bradley, S.E.; Laragh, J.H.; Wheeler, H.O.; MACDowell, M. and Olrver, J.: Correlation of structure and function in the handling of glucose by the nephrons of the canine kidney. J. clin. Invest. 40: 1113 (1961).

4. Burgen A.S.V.: A theoretical treatment of glucose reabsorption in the kidney. Canad. J. Biochem. 34: 466 (1956).

5. Calcagno P.L.: Aspects of renal function in prematurity; in Physiology of prematurity; Transactions of the 4th Conference (ed. Lanman, J.T.) pp. 170-171 (Josiah Macy, Jr. Foundation, Princeton, N.J. 1960).

6. GLARK, S.L.: Ingestion of proteins and colloidal materials by columnar absorptive cells of the small intestine in suckling rats and mice. J. biophys. biochem. Cytol. 5: 41 (1959).

7. Cohen, J.J.; Berglund, F. and Lotspeich, W. D. : Renal tubular reabsorption of acetoacetate, inorganic sulfate and inorganic phosphate in the dog as affected by glucose and phlorizin. Amer.J. Physiol. 184: 91 (1956).

8. Corcoran, A.C.: Glycosuria: mechanism and evaluation. Gleveland clin. Quart. 15: 186 (1948).

9. CRANE, R.K.: Intestinal absorption of sugars. Physiol. Rev. 40: 789 (1960).

10. Crane, R.K.: Hypothesis for mechanism of intestinal active transport of sugars. Fed. Proc. 21: 891 (1962).

11. Grane, R. K. : Personal communication.

12. EgGleton, G.: Cited in Robertson, J.A. and GRAx, C.H.: Mechanism of lowered renal threshold for glucose in diabetes. Lancet $i i$ : 12 (1953).

13. Froesch, E.R.; Winegrad, A.I. und Renold, A.E.: Die tubuläre Nierenfunktion bei verschiedenen Formen des renalen Diabetes mellitus. Helv. med. Acta 24: 548 (1957).

14. Goldring, W.; Chasts, H.; Ranges, H.A. and Smith, H.W.: Relations of effective renal blood flow and glomerular filtration to tubular excretory mass in normal man. J. clin. Invest. 19: 739 (1940).

15. Govaerts, P. and Muller, P.: The mechanism of glucose excretion by the kidney in diabetic dogs. J.clin. Invest. 18: 25 (1939).

16. Govaerts, P. et Lambert, P.P.: Pathogénie du diabète rénal. Acta clin. belg. 4: 341 (1949).

17. Keston, A. S. : Specific colorimetric enzymatic reagents for glucose. Abstracts, 129th Meeting Amer. Chem. Soc., p. 31 G (1956).

18. KRANE, S. M.: Renal glycosuria, in: The metabolic basis of inherited disease (ed. Stanbury, J.B.;

26 Pediat. Res., Vol. 1, No. 5 (1967)
WyngaArden, J.B. and Fredrickson, D.S.), chap. 53 (McGraw-Hill, New York 1966).

19. Lambert, P.P.: A study of the mechanism by which toxic tubular damage changes the renal threshold for glucose; in: Ciba Foundation Symposium on the Kidney (ed. Lewis, A.A.G. and Wolstenholme, G.E.W.), pp.79-95 (Little, Brown, Boston 1954).

20. Laplane, R.; Polonoviki, C.; Etienne, M.; DeBray, P.; Lods, J. C. et Pissarro, B. : L'intolérance aux sucres à transfert intestinal actif. Arch.franç. Pédiat. 19: 895 (1962).

21. Lindquist, B.; Meeuwisse, G.W. and Melin, K.: Glucose-galactose malabsorption. Lancet $i i: 666$ (1962).

22. Lindquist, B. and Meeuwisse, G.W.: Ghronic diarrhoea caused by monosaccharide malabsorption. Acta paediat. 51: 674 (1962).

23. Lindeuist, B. and Meeuwisse, G.W.: Intestinal transport of monosaccharides in generalized and selective malabsorption. Acta paediat. Suppl. 146: 110 (1963).

24. Lindquist, B.; Meeuwisse, G.W. and Melin, K.: Osmotic diarrhoea in genetically transmitted glucose-galactose malabsorption. Proc. Swedish Paediatric Soc. Acta paediat. 52: 217 (1963).

25. LiNNEWEH, F.: Unverträglichkeit von Nahrungseiweiß und -zuckern auf der Basis cellulär-metabolischer Defekte. Klin.Wschr. 43: 1 (1965).

26. Linneweh, F.; Schaumlöffel, E. und BarthelMAI, W.: Angeborene Glucose- und GalaktoseMalabsorption. Klin.Wschr. 43: 405 (1965).

27. Liu, H.Y.; Tsao, M.U.; Moore, B.F.; Gidax, Z. and Anderson, G.: Intestinal and renal malabsorption of monosaccharides. Abstracts, Amer. Pediatric Soc. 75th Annual Meeting, p. 42 (Philadelphia 1965).

28. Liu, H.Y. and Tsao, M.U.: A case of intestinal and renal malabsorption of monosaccharides. Amer.J. Dis. Child. (to be published).

29. Lotspeich, W.D. and Woronkow, S. : Some quantitative studies on phlorizin inhibition of glucose transport in the kidney. Amer.J. Physiol. 195: 331 (1958).

30. Lotspeich, W.D.: Metabolic aspects of renal function (Thomas, Springfield 1959).

31. Lotsperch, W.D. : Phlorizin and the cellular transport of glucose. Harvey Lect. 56: 63 (1961).

32. Marks, J.F.; Norton, J.B. and Fordtran, J. S. : Glucose-galactose malabsorption. J. Pediat. 69: 225 (1966).

33. Mrrskx, I.A. and Nelson, N.: Significance of glycosuria. Arch.intern. Med. 71: 827 (1943).

34. Mudge, G.H.: Clinical patterns of tubular dysfunction. Amer.J.Med. 24: 785 (1958). 
35. Nielsen, A.L.: On the mechanism of glycosuria. I. Acta med.scand. 130: 219 (1948).

36. Nielsen, A.L.: On the mechanism of glycosuria. II. Factors affecting the appearance and duration of glycosuria. Acta med.scand. Suppl. 213: 273 (1948).

37. Reubr, P.F.: Recherches sur le diabète rénal, Y. Le mécanisme de la glycosurie. Helv. med. Acta 18: 69 (1951).

38. ReUBi, P.F.: Glucose titration in renal glycosuria; in: Ciba Foundation Symposium on the Kidney (ed. Lewis, A.A.G. and Wolstenholme, G.E.W.), pp.96-113 (Little, Brown, Boston 1954).

39. Rhodin, J.: Electron microscopy of the kidney. Amer.J. Med. 24: 661 (1958).

40. Riklis, E. and QuAstel, J.H.: Effects of cations on sugar absorption by isolated surviving guinea pig intestine. Canad.J. Biochem. 36: 347 (1958).

41. Robertson, J.A. and Gray, C.H.: Mechanism of lowered renal threshold for glucose in diabetes. Lancet ii: 12 (1953).

42. Sahneider, A.J.: Glucose-galactose malabsorption. Abstract, Amer.Pediatric Soc., 75th Annual Meeting, p. 54 (Philadelphia 1965).

43. Schneider, A.J.; Kinter, W.B. and Stirling, C. E. : Glucose-galactose malabsorption. New Engl. J.Med. 274: 305 (1966).

44. Schreiner, G.E.: Modification of the Roe, Epstein and Goldstein method. Proc. Soc. exp. Biol. (N.Y.) 74: 117 (1950).

45. Shannon, J.A. and Frsher, S.: The renal tubular reabsorption of glucose in the normal dog. Amer. J. Physiol. 122: 765 (1938).

46. Shannon, J.A.; Farber, S. and Troast, L.: The measurement of glucose $\mathrm{Tm}$ in the normal dog. Amer.J. Physiol. 133: 752 (1941).

47. Smith, H.W.; Goldring, W.; Ghasis, H.; RanGES, H.A. and BRADLEy, S. E. : The William Henry Welch Lectures. II. The application of saturation methods to the study of glomerular and tubular function in the human kidney. J. Mt Sinai Hosp. 10: 59 (1943).
48. Smrth, H.W.: The kidney: Structure and function in health and disease (Oxford University Press, New York 1951).

49. Sмiтh, H.W.: Principles of renal physiology (Oxford University Press, New York 1956).

50. Steigerwald, H.: Diskussion; in: Die tubuläre Nierenfunktion bei verschiedenen Formen des renalen Diabetes mellitus (ed. Froesch, E. R.; WinEGRAD, A.I. und Renold, A.E.). Helv.med. Acta 24: 548 (1957).

51. TAGgART, J.V.: Mechanism of renal tubular transport. Amer. J.Med. 24: 774 (1958).

52. Tudvad, F.: Sugar reabsorption in prematures and full term babies. Scand.J.clin. Lab. Invest. $1: 281$ (1949).

53. Tudvad, F. and Vesterdal, J.: Maximal tubular transfer of glucose and para-amino-hippurate in premature infants. Acta paediat. 42: 337 (1953).

54. WilbrandT, W.: Secretion and transport of nonelectrolytes. Symp. Soc. exp. Biol. 8: 136 (1954).

55. WrLson, T.H.: Intestinal absorption (Saunders, Philadelphia 1962).

56. The authors express their gratitude to Dr. JOSEPH P. CHANDLER of the University of Michigan Clinical Research Unit Laboratory for the analyses of plasma and urinary inulin; to Dr. MARIon DEWEESE of the Department of Surgery for performing the arterial catheterization; to Miss LindA Hiratsuka for her expert nursing assistance; and to Drs. Richard L. Malvin and Arthur Vander of the Department of Physiology for their invaluable criticism.

57. Supported by Research Grant AM-08494 from the National Institutes of Health; H.H. Rackham Research Grant No.604; and Public Health Service Research Grant 5MOI-FR-42-04 from the Division of Research Facilities and Resources.

58. Lru, Hsr-Yen, M.D., Associate Professor, Department of Pediatrics and Communicable Diseases, University of Michigan Medical School, Ann Arbor, Mich. 48104 (USA). 